\title{
GIS Application and Architectural Design for the Assessment of Urban Infrastructural Renovation: Case of the Nsam Market in the Yaounde III Municipality, Cameroon
}

\author{
Elvis Kah*, Tang Somo Alain \\ University of Yaounde I, FALSS, Department of Geography, Yaounde, Cameroon \\ Email: *kah_elvis@yahoo.fr, elvis18289@alumni.itc.nl
}

How to cite this paper: Kah, E. and Alain, T.S. (2021) GIS Application and Architectural Design for the Assessment of Urban Infrastructural Renovation: Case of the Nsam Market in the Yaounde III Municipality, Cameroon. Journal of Geographic Information System, 13, 369-394. https://doi.org/10.4236/jgis.2021.134021

Received: May 20, 2021

Accepted: July 10, 2021

Published: July 13, 2021

Copyright $\odot 2021$ by author(s) and Scientific Research Publishing Inc. This work is licensed under the Creative Commons Attribution International License (CC BY 4.0).

http://creativecommons.org/licenses/by/4.0/

\begin{abstract}
Markets, whose creation needs heavy investment, are seen as centres for economic and financial transactions. To this effect, they play an important role in the survival of city dwellers as well as the embellishment of the city. In 2006, Nsam market was created in the Nsam quarter Yaounde with little financial concentration. Over the years, this market has outlived its usefulness to the extent that its present functioning is an eyesore. Amongst the causes to this are the facts that, the market was created following no predefined standards, the city has grown and the market can no longer handle the dependent population. From field observations, this study aimed at proposing a complete renovated plan for the Nsam market in Yaounde, Cameroon. The study relied on secondary and primary sources of data collected and treated following some pre-set standards. These data enabled an analysis of the diagnosis of the situation prevailing there where it led to the conclusion of a complete renovation of the market. This renovated market is expected to better the working conditions of traders, create more jobs which will boost revenue collection and embellishment of the city amongst others.
\end{abstract}

\section{Keywords}

Renovation, Embellishment, Diagnosis, Market, Nsam, Yaounde

\section{Introduction}

The fact that Cameroon lived through different colonial authorities, the texts governing town planning also evolved under the different administrations. Though the Germans, the French, the British and the independent Cameroon 
government provided these texts, their application left much to be desired. Thus, with limited application of these texts, most towns in Cameroon grew without any pre-conceived plan, no Master Development Plans and no landscape planning. These towns could only witness restructuring, rehabilitation operations and urban renewal in a bid to improve upon the settled areas through the construction of new infrastructure and durable urban equipment [1].

Note should be taken that Cameroon is a country in full transition. Between 2010 and 2020, urbanisation rate stood at 1.05\%. Its administrative capital Yaounde and the economic capital Douala serve as poles of complex financial centres at the national and international levels. The growth of enterprises in these two cities as well as the mobility of capital have orchestrated the appearance of new exchange places in the face of rhetoric and ill-conceived decentralisation process in the country [2].

The creation and building of new markets in Cameroon fall within the competence of administrative and local collectivities (councils). Most often this generates conflict of interest because in most cases, the creation and construction of a market is financed from Public Investment Budget (PIB) or by FEICOM while its maintenance and management are ensured by the council. In the process of creating a new market, no matter the financing authority, the council has to play a primordial role by choosing the site and even technically selecting the contractor from the bidders [3]. To that effect therefore, the location of a market within a city is never haphazard, much preliminary work must have to be done. They are never where they are located because there was available space but because the council used other means to acquire the space.

Since most of the markets in the cities of Yaounde and Douala in Cameroon exist with no pre-conceived plans, they are considered as areas of insecurity, areas of urban decay, areas of insalubrity, areas of urban disorder that reflect urban poverty. Councils being the appropriate bodies that manage, improve and embellish the urban space are rather in constant conflict with the administrative authorities as who is to do what within the town. In this wise most councils rather concentrate their financial resources in building and renovating council premises into gigantic structures, some of them serving as touristic centres within the towns [4].

The crisis in managing urban space in Cameroon results from a number of observations made at the national level. Firstly, most if not all of the urban actors are not town planners or landscapers. The decision makers have no basic training in the field of town planning. They are simply politicians whose decisions go to satisfying politics rather than the technical aspects in town planning. The consequence is that the growth of the towns follows no logic-whether in environmental conservation, preservation of patrimony or for industrial perspective [5]. From this point of view one clearly sees that the choosing of the Nsam market site in Yaounde was to satisfy political objectives rather than adequately and rationally serving the people in that part of the city. Such decisions often lack the accompanying measures, reason why the Nsam market according to the Yaounde 
City Orientation Plan (YCOP) by 2020 provides for its reconstruction and improvement of the site. This study therefore aims at proposing a masterpiece of the improved new site with the help of Geographic Information System (GIS) [6].

\section{Materials and Methods}

\subsection{The Study Area}

Nsam market is located in the Nsam neighbourhood within the Yaounde $3 \mathrm{mu}$ nicipality. As reference, it is bounded in the north by SCDP storage tanks (a petroleum retail company in Cameroon), in the east by River Mfoundi, in the south by Garanti Express (a travel Agency) and in the west by the main street leading to the city centre.

According to the Yaounde Urban Orientation Plan (PDU) which spans up to 2020 and made available in 2004 by the city council, the whole city was to benefit from a vast restructuring programme. In this wise, markets were to be rebuilt, restructured or new ones constructed. This vast programme was to be handled by MAETUR, SIC and CFC put in place by the government whose combined actions are destined to designing adequate lodging policy on national reserves throughout the national territory. These structures had to depend on expert knowledge in order to accomplish their respective missions. MAETUR for example whose mission is to prepare construction sites must rely on GIS, SIC on the other hand whose mission is to realise the structures depends on architects while CFC put in place to provide the necessary funding relies on the pro-forma established by the other two structures [7].

Nsam market, whose creation seemed not to have benefited from any prior planning falls within this vast restructuring programme in Yaounde. Though with a limited surface area on a sloppy terrain, the authorities debated on its complete relocation but no new site in the proximity could be obtained. Thus, this study based on the present site which is hoped the powers that be will take advantage and implement the project. Figure 1 is a location of the Nsam market in a wider spectrum while Figure 2 locates it within Nsam quarter in Yaounde.

\subsection{Methodology Adopted}

Understanding both physical and social environments is a prerequisite for planning and implementation of community-based development projects. It is in this perspective that many authors have dwelled on this amongst whom we have Claudia R. Williamson (2009) [8] noted that digital information about land is central to the policy framework of modern land administration and sustainability. To ensure that land administration and management decisions are consistent to sustainable development principles, land information systems must integrate a wider range of data, information and knowledge. Policy goals cannot be achieved unless there are effective land administration infrastructures with modern information technology providing effective citizen access to information. Effective 


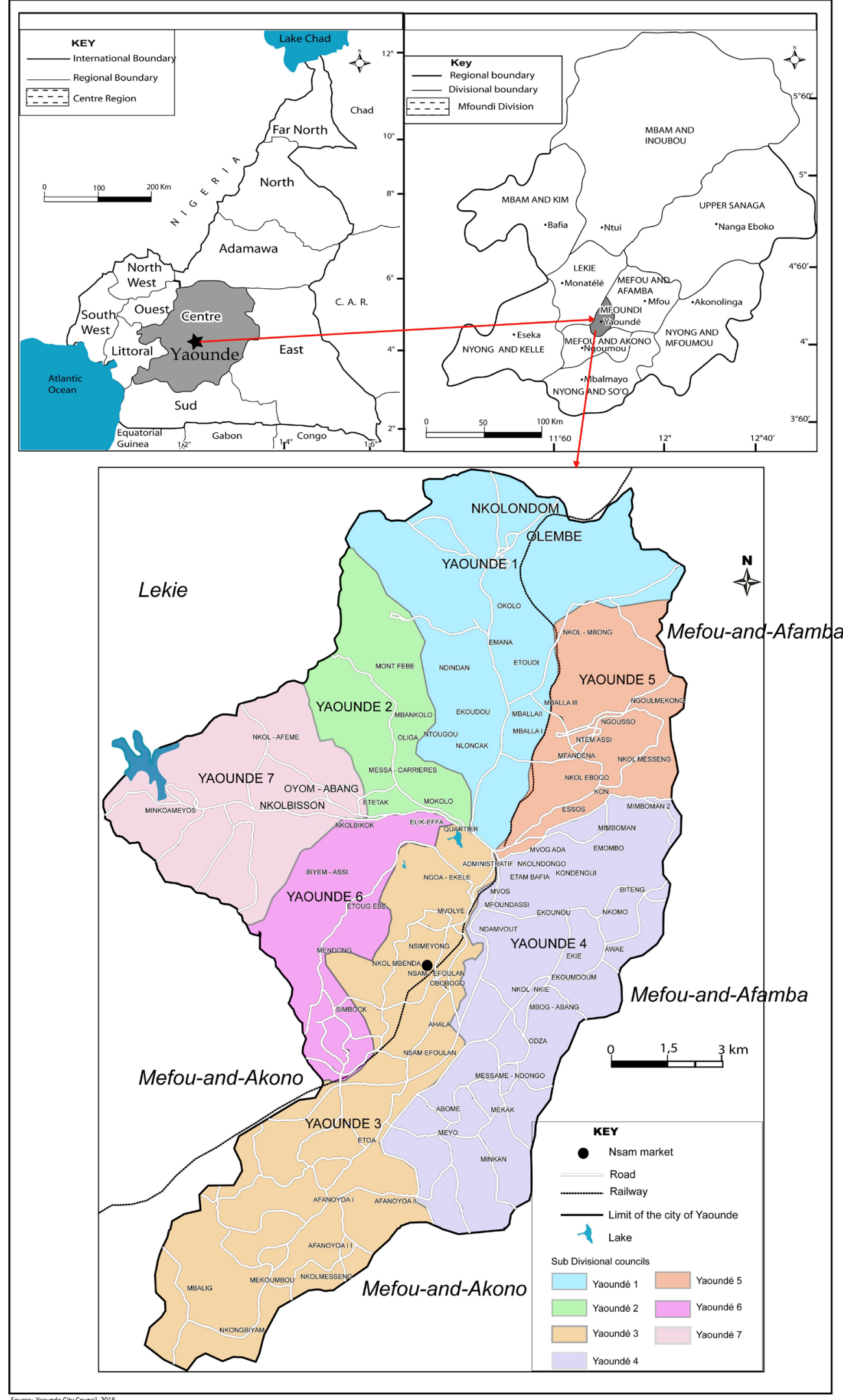

Figure 1. Location of the Nsam market in the Yaounde III municipality. Source: Adapted from the topographic map sheet of Bafoussam NB 32-X. 


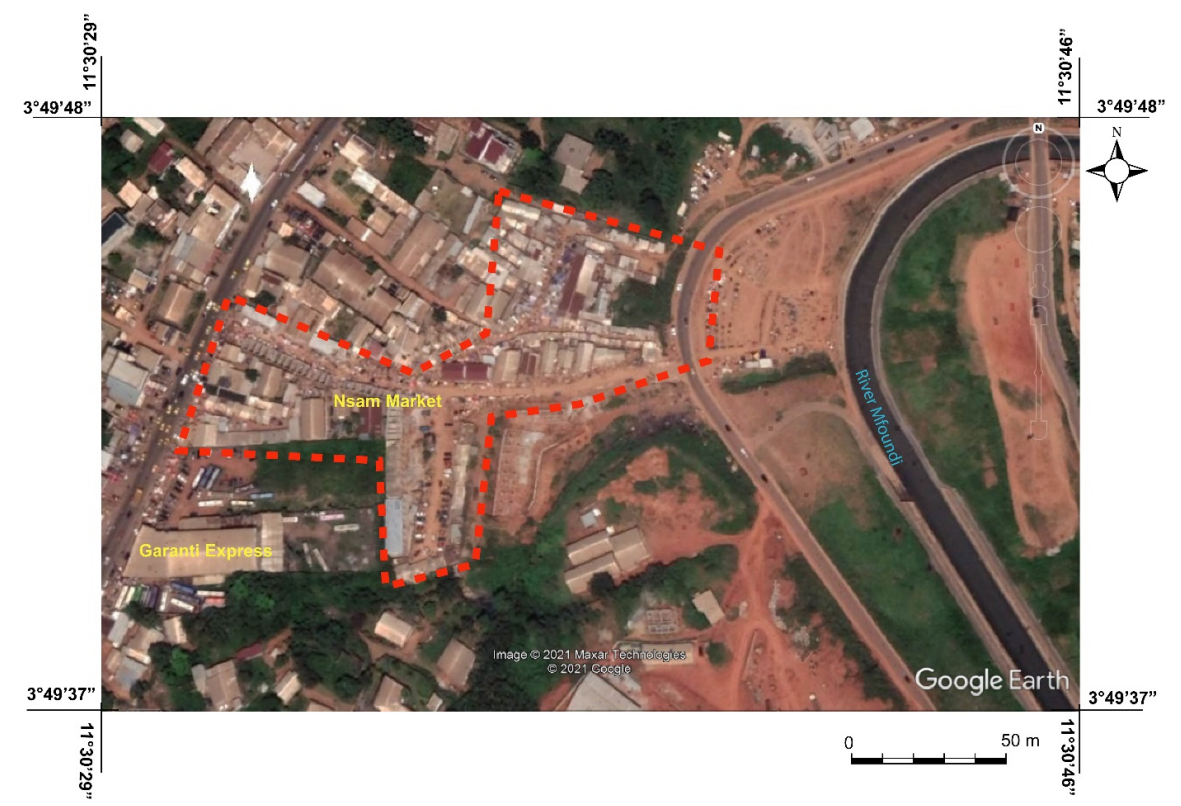

Figure 2. Aerial view of the Nsam market in Yaounde.

administration involves the participation of the poor and disadvantaged (especially the poor and marginalized groups) in decision making process.

These authors pointed out that there has been a gradual shift/revolution in land administration practices over the centuries; passing from the primitive system of the old in the $19^{\text {th }}$ century to today's heterogeneous and complex society warranting more sophisticated procedures of land assessment and control. Unfortunately enough, modern societies in their response to the demands and needs for sustainable development are not doing enough in current land administration practices because of the overlapping rights, restrictions and responsibilities related to land.

This knowledge makes us to understand that we either do upgrading or renovating land either within a rural setting or an urban space. Urban upgrading is broadly defined as physical, social, economic, organizational, and environmental improvements undertaken cooperatively among citizens, community groups, businesses and local authorities to ensure sustained improvements in the quality of lives for individuals. In this wise the objective of urban renovation is to attain urban upgrading. So the collection of data focused towards this direction.

\subsubsection{Collection of Secondary Data}

Three main aspects constituted the methodology of this study, they include, documentary research, collection of primary source data and the treatment and analysis of the treated data. As for documentary research, the following institutions were visited where existing material were consulted. These were the Yaounde III Council documentation centre, libraries in the University of Yaounde I, French Cultural Centre in Yaounde, Advanced School of Public Works Yaounde etc (Table 1). The data collected were in direct relation with the project envisaged to be executed. 
Table 1. Type of data collected and their sources.

\begin{tabular}{ll}
\hline \multicolumn{1}{c}{ Data collected } & \multicolumn{1}{c}{ Source of data } \\
\hline $\begin{array}{l}\text { Socio-economic and demographic data on } \\
\text { Nsam market }\end{array}$ & Yaounde III Council Library \\
State of electrical network in Nsam market & ENEO (Electricity corporation in Cameroon) \\
& $\begin{array}{l}\text { Libraries of University of Yaounde I, French Cultural } \\
\text { Cocumentre, National Advanced School of Public Works, }\end{array}$ \\
& \begin{tabular}{l} 
Yaounde III Council Library and many internet websites \\
\hline
\end{tabular}
\end{tabular}

\subsubsection{Collection of Primary Data}

In order to attain the expected results for this study, the method employed consisted of sampled investigation which presents a certain number of stakes and carried out in well distinct stages. It should be noted that there are three advantages when using this method. They include 1) cost and rapidity, 2) flexibility in the choice of techniques and 3) precision and the quality of the information generated.

This approach relies on many articulations which are:

- Defining the objectives and the population to be studied. Here we first sorted to know the present and future needs of the population in order to determine the nature of the investigation. Before this, the target population was clearly defined.

- Secondly, precising the investigation and the sample size. Here the study depended on the amount of data collected. The data collected enabled us to determine the sample size within the limit of the budget allocated for this.

- Thirdly, executing the sample survey. The objective here was to limit to the collection of relevant data. This was done through the administration of questionnaires coupled with documentary research as well as semi-structured interviews.

Those to whom the questionnaire was administered were the regular commuters at the Nsam market which include trade unionists (road transporters, truck pushers, traders and buyers etc) and quarter heads who command around the market area. In the process of administering the questionnaire, some observations were made which enable us to establish the extent of precariousness, the needs of the commuters and perception about the market. Care was taken to ensure that the sampled population represented all the groups of the population that treat with the Nsam market. The multiple fieldwork carried out in October 2018 were aided by three guides who had obtained prior training to that effect. These were punctuated by semi structured interviews with the quarter heads, representatives of the different trade unions etc on how commercial activities go on in the market, leisure, space occupation and maintenance of existing infrastructure. Table 2 summarizes the activist carried out during the fieldwork.

\subsubsection{Data Treatment and Exploitation}

Given the manner in which the questionnaire was structured, each form was codified according to the sector of activity then followed by encoding and statistical 
Table 2. Recapitulation of the sampled population.

\begin{tabular}{ccccc}
\hline Target population & $\begin{array}{c}\text { Traditional chief of the Nsam } \\
\text { quarter, quarter heads }\end{array}$ & $\begin{array}{c}\text { Administrative } \\
\text { actors }\end{array}$ & $\begin{array}{c}\text { Real estate } \\
\text { promoters }\end{array}$ & $\begin{array}{c}\text { Members of } \\
\text { trade bunions }\end{array}$ \\
\hline Number interviewed & 11 & 04 & 02 & 08 \\
\hline
\end{tabular}

analysis of all the forms administered in the field. Codification here consisted of attributing a code number to each variable of the questionnaire so as to introduce it to the computer for easy analysis. The codes were in digital numbers in order to avoid errors during the tabulation of the results.

Data treatment and analysis were carried out precisely on the collected data from the field. To better execute this work, the following softwares were used.

- ArcGIS 10.5, with which spatial analysis was done, Google Earth image from where the aerial view of the study area was captured, a graphic of KMZ extension was elaborated. The KMZ file was the transformed to DWD file to be read by Archicad software

- Archicad 22, it is with this software that the real dimension of the study area was extracted.

Next was the elaboration of the present state of the area and transformed to a PDF file. Finally this software also aided in elaborating the technical study of the whole project beginning from the conception, calculating the dimensions and calculating each work to be done. The architectural plans for each structure in the market were generated in PDF files.

Finally, Microsoft Excel aided in effectuating statistical studies of the data collected such as the sum, averages, variances, standard deviations, maximums and minimums. While Microsoft Word was used in typing the final draft containing the elaborated figures, tables, graphs and maps to better illustrate the results of the study.

\section{Results}

\subsection{Nsam Market, a "Sacred Garden" of Urban Disorder}

Although located within the largest municipality in Yaounde in terms of surface area (6800 ha), Nsam market squishes itself between Garanti Express Agency, SCDP and River Mfoundi. Its proximity to emerging quarters of Yaounde confers to it a strategic position that could be taken advantage of. Such advantage had not been exploited first because the site on which the market was built is sloppy ranging from $697 \mathrm{~m}$ in the middle part of the market to about $718 \mathrm{~m}$ on both ends. The section closest to the river serves as a waste dumping ground thus rendering the area too nasty and smelling. Worst still, one finds petit traders placing their goods on waste heaps and resist the bad odours every day as they frequent the market to sell. This condition became improved in 2009 when River Mfoundi benefited from the vast canalisation sponsored through the PDU programme of Yaounde [9].

As already noted above, Nsam quarter and its environs is an emerging quarter 
which is believed to have benefitted from prior planning. Unfortunately this seems not to have been the case as one finds commercial buildings juxtaposing residential houses, gigantic collective residential houses interspersed by tattered houses, churches characterised by their loud noises mingling inside the quarters, schools with no spaces located close to beer parlours. This poorly placed activities produced a pathetic incident in 2001 when over 200 people died as they were trying to collect leaking fuel from a fallen petrol tanker that caught fire at the SCDP depot.

This disorder is even more accentuated along the main streets of the quarter, that is, the street at the outlet towards Douala via Nsam Escale, the one leading Damas neighbourhood via Obobogo and the one leading to the city centre via Olezoa. About $95 \%$ of the roadside houses are for commercial purposes. Since there are no norms governing the location of commercial activities on the streets, the situation here is chaotic. One finds hardware stores side by side with restaurants, shops of used dresses juxtaposing churches, tailoring workshops with Hitech shops, groceries placed alongside carpenter workshops, cosmetics stores close to hotels etc. This picture is what prevails in the Nsam market [10]. In 2006 when this market was constructed by the Yaounde III Council, a large shed otherwise known as grand hangar was erected with wood inside the market. This grand hangar is partitioned into sale booths where fresh meat is sold. Fragile bowers roofed with old corrugated iron sheets spread in all directions around the grand hangar. During wind storms, some of them do not resist are often subjected to rebuilding.

Apart from the grand hangar occupying a privileged place in the market, there are also stores built in similar temporal materials (wood) where goods are stored. The manner in which they are arranged present enormous risk to the extent that with a strike of fire, everything will be consumed by flames. It is also very easy for thieves to break into the stores and cart away with all the goods. From field investigation, it should be noted that most of the building materials used in constructing the Nsam market are wood (83.4\%), corrugated iron sheets $(4.1 \%)$ and thatch houses (12.5\%). The wood used can be sub divided into four groups-planks mostly of white wood of $0.03 \times 0.03 \times 5 \mathrm{~m}$ representing $48.2 \%$, followed by rafters also of white wood $0.07 \times 0.07 \times 5 \mathrm{~m}$ representing $17.4 \%$, lath of white and red wood of $0.03 \times 0.07 \times 5 \mathrm{~m}$ representing $26.7 \%$ and finally "carabot" of red wood representing $7.7 \%$. All these temporal and fragile structures are mostly roofed with old corrugated iron sheets while others are with plastic tarpaulins.

As concerns the exposition of goods in the market, this is another eyesore. What strikes most is that the goods are placed on bare ground along all the passages in the market. Traders that occupy the sale booths extend their goods to the door either on the ground or on tables to the extent that they narrow passages giving room for congestion and creating avenues for thieves to do what they are best of (Figure 3 and Figure 4). Most of these traders are women retailing all sorts of goods that range from cereals, fruits, vegetables, cooking oil etc. Men mostly deal with meat while most of the buyers are women [11]. 


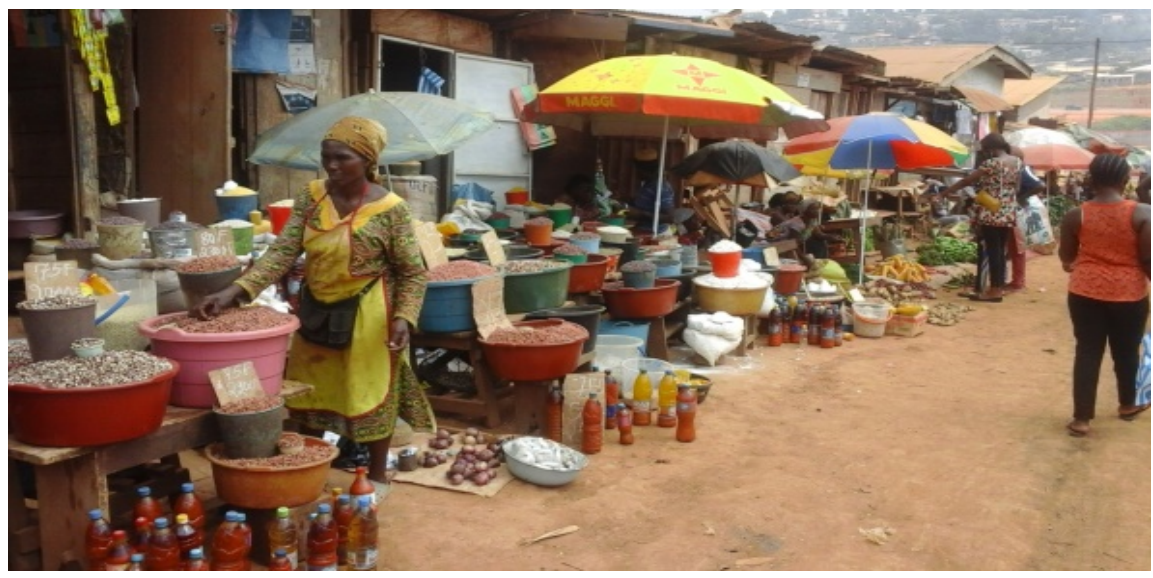

Figure 3. Market goods extending to block the passage ways.

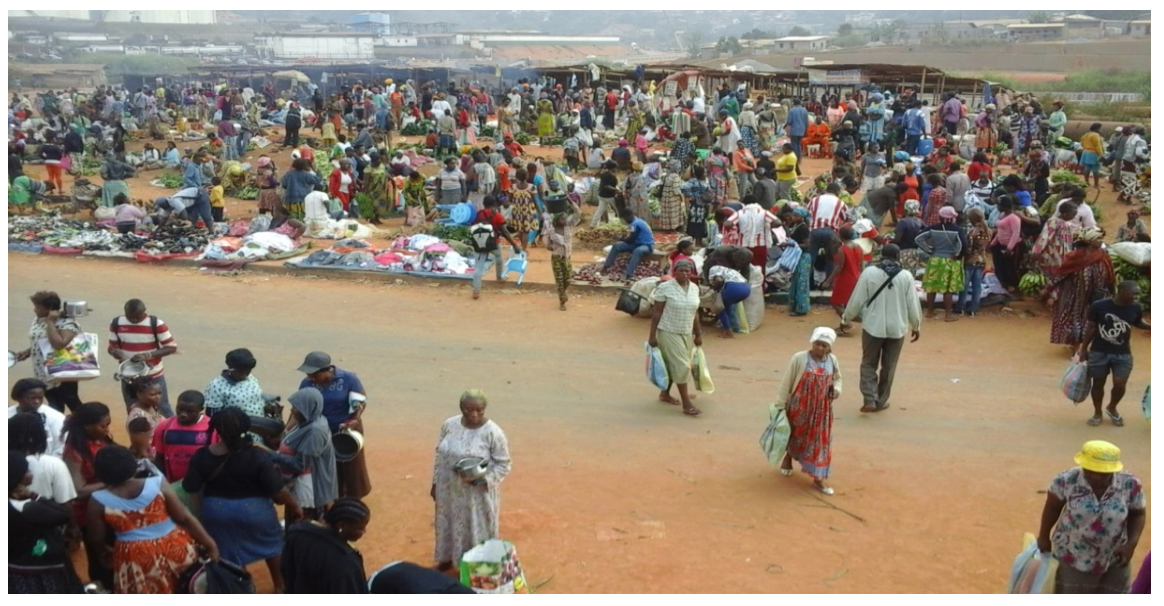

Figure 4. Disorder at the extension side.

The sale of fowls occupies the NE part of the market. The chickens on sale are placed in wooden boxes associated with wire nets. Youths employ themselves in cleaning the fowls as well as burning cow skin in very risky situations which include insalubrity, exposure to the sun and rain and bad odours. The safe haven of urban disorder in the Nsam market is further compounded by a precarious and dangerous electrical connection. These connections are in such a way that if fire catches on one end, it will easily raise down the entire market. With narrow and slim passages the effort of fire fighters can certainly be in vain. Field investigation enabled us to conclude that these electrical connections are done by the traders themselves with little or no knowledge on electricity.

For example the pathetic situation is the fact that there is a motor park at the centre of the Nsam market which serves villages around the city such as Mbankomo, Ngoumou, Bikok, Oveng, Afanoyoa, Akono and Olam who bring in foodstuffs and fruits to sell to the city dwellers. Today this park has been transformed to a sanctuary of abandoned cars, garage and garbage of dirt heaps. Figure 5 and Table 3 show the rate of frequency to Nsam market and transport cost to the surrounding villages [12]. 


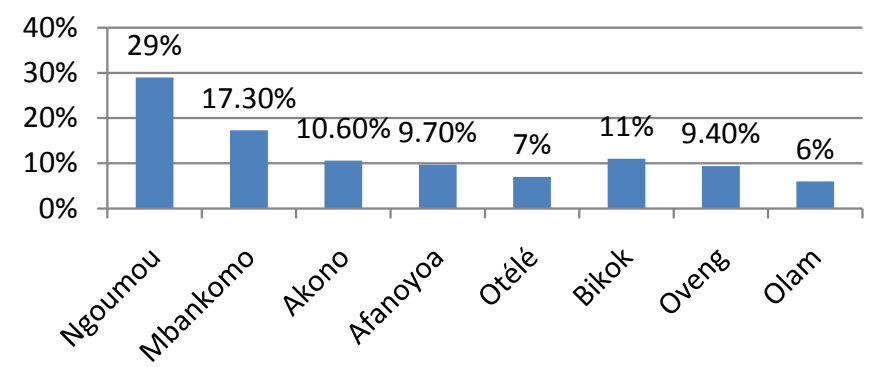

Figure 5. Rate of frequency to and from the localities around Yaounde. Source: Fieldwork 2018.

Table 3. Tariffs to and from the different localities around Yaounde.

\begin{tabular}{cccc}
\hline Destinations & Tariff $($ FCFA $)$ & Destinations & Tariff $($ FCFA $)$ \\
\hline Akono & 700 & Ngoumou & 500 \\
Afanoyoa & 400 & Olama & 600 \\
Bikok & 800 & Otélé & 700 \\
Mbankomo & 400 & Oveng & 800 \\
\hline
\end{tabular}

Source: Fieldwork 2018 and [13].

The transport costs to these different localities are presented as on Table 3. Figures 6-8 illustrate the aspects of disorder in the Nsam market while Figure 9 shows the present disposition of the Nsam market.

\subsection{Proposed Architectural Renovation of the Nsam Market}

Following the fact that Nsam market is located in an emerging quarter in Yaounde, a befitting market had been earmarked from the Yaounde City Strategic Plan, horizon 2020 [14]. Tenders had been opened to this effect and the city council is still to validate a proposed architectural plan. According to the diagnosis of the existing situation, these researchers set out certain objectives before proposing a project for the new market. These objectives which result from the feasibility studies and intensive fieldwork are summarised on Table 4.

The essence of this study is to create a concerted management zone (CMZ). It is a tool for urbanisation whereby an area can be constructed on one hand and on the other hand a poorly planned area can be re-absorbed. This is often practiced in urban fringes which are yet to be intensified or in areas with a negative view. Land in such situations is often acquired through what is referred to as Urban Pre-emption Law or Urban Reinforced Pre-emption Law [15]. The local population take cognisance of such a situation through arbitrary political decisions which sometimes lead to social unrest. This now gives rise to renovation which is defined by Decree $\mathrm{N}^{\circ} 2008 / 0738 / \mathrm{PM}$ of the $23^{\text {rd }}$ of April 2008 as a set of measures and planning operations that consist of total or partial demolition of dilapidated or in-adapted urban sector in other to raise new structures. This entails the use of new and modern construction materials that will replace the destroyed or obsolete parts [16]. Brief, it consists of a new structure put up after 


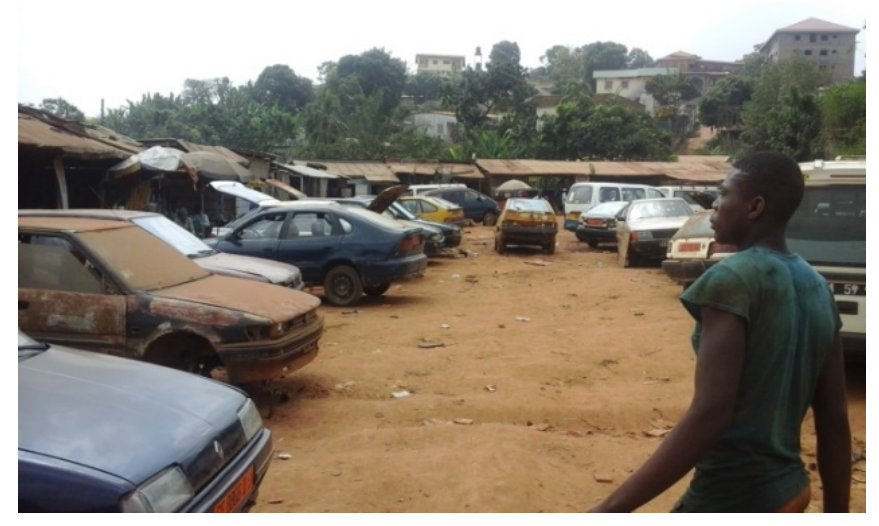

Figure 6. Nsam motor park (notice the dusty or muddy ground).

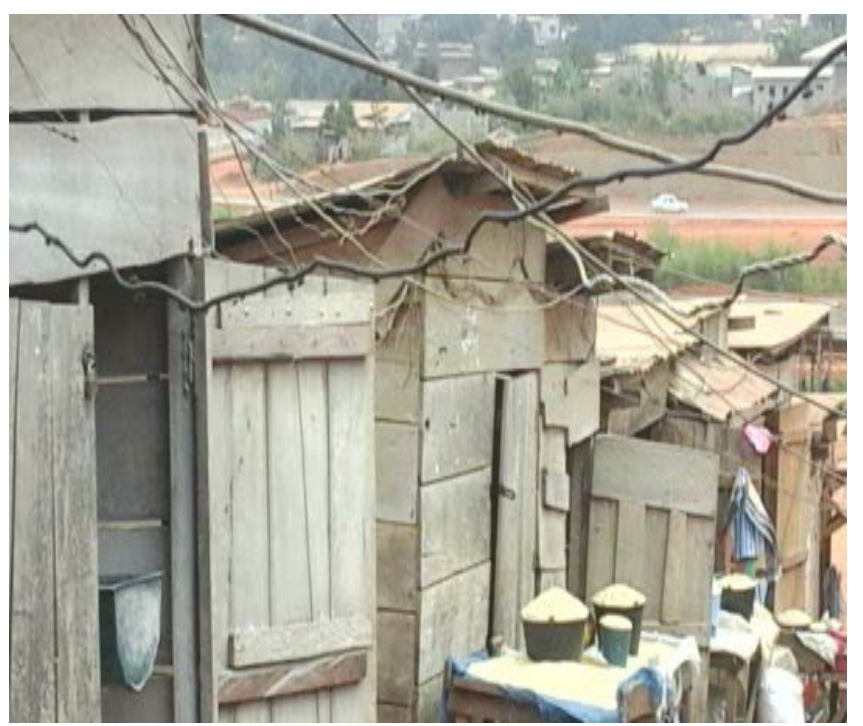

Figure 7. Market stores (warehouses). Notice the poor building materials and the passing of electrical cables.

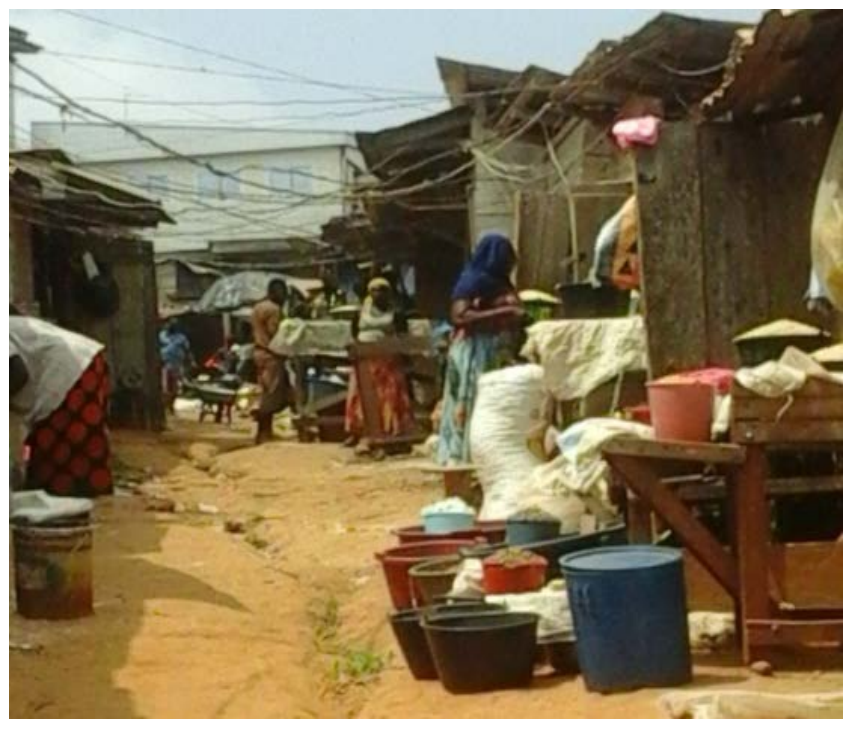

Figure 8. Market stores. Notice the passing of electrical cables. 


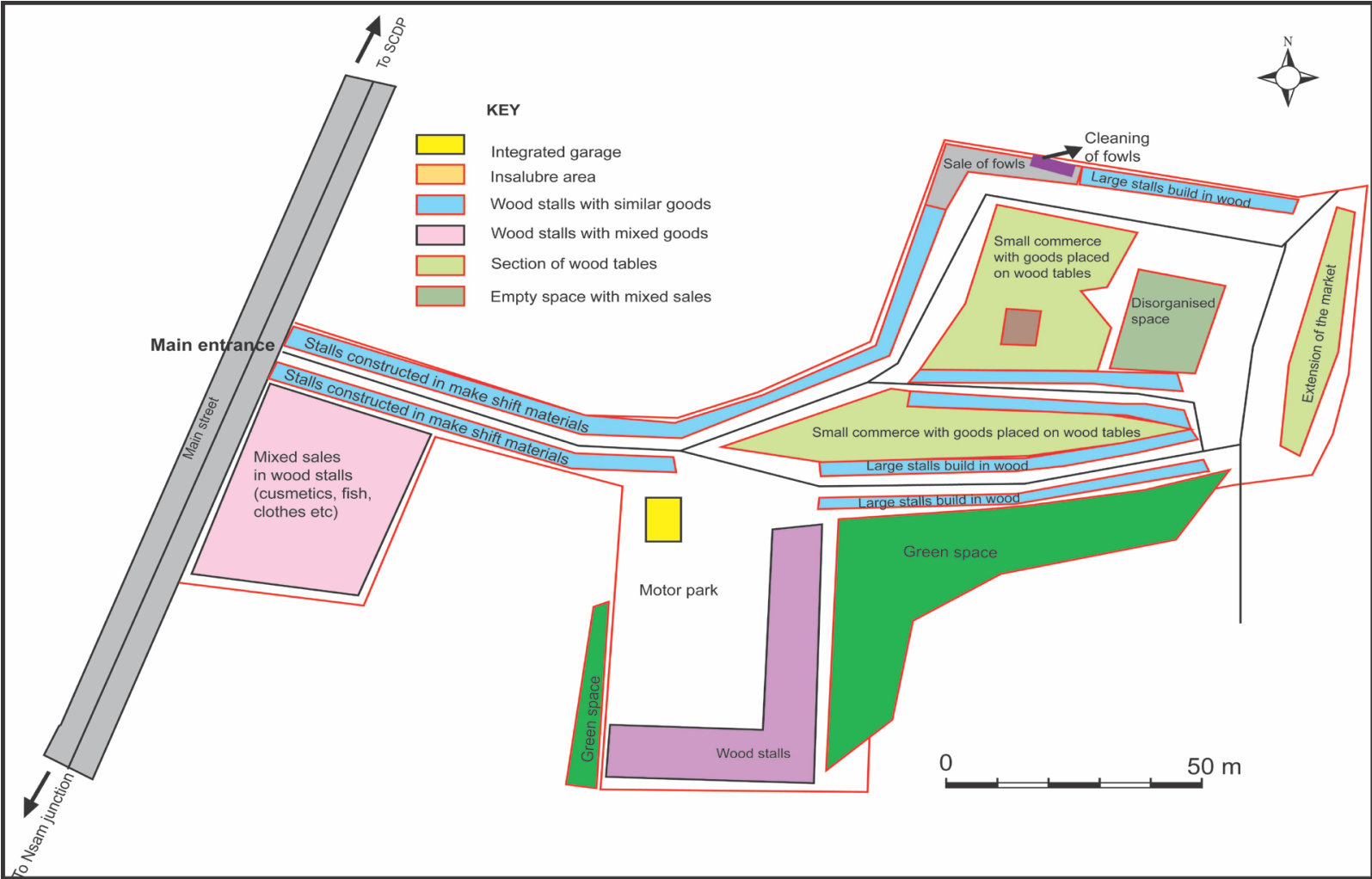

Figure 9. The present "sacred garden" of urban disorder in Nsam market.

Table 4. Objectives of the renovation of the Nsam maeket.

\begin{tabular}{|c|c|}
\hline Objectives & Expected outcome \\
\hline Improve upon the built area & $\begin{array}{l}\text { - Avoid the placing of goods on the ground } \\
\text { - Eliminate the insecure and wood hangars } \\
\text { - Provide security to the stores (warehouses) } \\
\text { - Avoid the display of goods under the sun } \\
\text { - Improve the working conditions of sellers } \\
\text { - Provide parking spaces for users } \\
\text { - Make the entrance into the market more visible }\end{array}$ \\
\hline Render the market more accessible & $\begin{array}{l}\text { - Eliminate traffic jam at the main entrance to the market } \\
\text { - Provide security to parked vehicles and stored goods } \\
\text { - Facilitate the circulation of people in the market }\end{array}$ \\
\hline Facilitate access to potable water & $\begin{array}{l}\text { - Ensure that water is of good quality } \\
\text { - Create avenue for the reduction of water related diseases } \\
\text { - Create many water points in the market } \\
\text { - Ensure that toilettes function optimally }\end{array}$ \\
\hline $\begin{array}{l}\text { Improve the management } \\
\text { of electricity }\end{array}$ & $\begin{array}{l}\text { - Eliminate clandestine electrical connections } \\
\text { - Reduce the risk of fire incidents } \\
\text { - Create facilities to conserve goods } \\
\text { - Ensure constant electricity with acceptable voltage } \\
\text { - Regulation of electrical services } \\
\text { - Reduce bandits in the market }\end{array}$ \\
\hline $\begin{array}{l}\text { Put in place adequate } \\
\text { clean-up system }\end{array}$ & $\begin{array}{l}\text { - Ensure a better management of waste } \\
\text { - Reduce pollution } \\
\text { - Reduce diseases related to insalubrity } \\
\text { - Eliminate nasty zones in the market } \\
\text { - Better channel runoffs resulting from rain }\end{array}$ \\
\hline
\end{tabular}




\section{Continued}

\begin{tabular}{cl}
\hline \multirow{2}{*}{ Improve upon the } & - Ensure security of users in the market \\
passages inside the market & - Aerate the market for easy mobility \\
& - Increase the number of sellers and buyers in the market \\
& - Ensure security of passengers \\
& - Create parking for users \\
- & Better management of the space \\
- Pe-organise the motor park & - Eliminate garbage heaps \\
& - Remove all the abandoned cars \\
- Surveillance of the market in all the sectors \\
Promote the security & - Creation of jobs \\
& - Create an enabling environment for the population
\end{tabular}

Source: Authors' conception.

the total demolition of an old one. This differs from restauration which refers to putting back the structure at its initial state and rehabilitation whose objective is to reopen a structure that had been closed. Thus renovation can be attributed to a town, a quarter or urban infrastructure (market, stadium, Motor Park, church, school etc.). Renovation is often conceived by a council or the state. In Cameroon, this policy has often been criticised since many stakeholders are involved with no clear cut tasks [17]. The project mounted for this market is to completely renovate the Nsam market.

According to Article 4 of Decree $\mathrm{N}^{\circ} 2008 / 0738 / \mathrm{PM}$, the procedures and modalities for the execution of land projects must be fixed by the state, the council, the Ministry of Urban Development and Housing (MINHDU) or Urban Common Initiative Groups. As this project aims at submitting to the council following the tenders that were opened, the renovation is in pursuance of the objectives stipulated by Law $\mathrm{N}^{\circ} 2004 / 003$ of the 21/04/2004 (Article 54) governing Town Planning in Cameroon. Yaounde III Council in opening the tenders wrote a proposal that was accompanied by observations made on the field, complaints from the local population addressed to the Minister of Urban Development and Housing. The Ministry in turn deliberated on it for 60 days and issued an Order authorising the council to open tenders for bidders. The Order of the Minister fell within the context of the dispositions of Article 5 of Urban governing Decree in Cameroon. According to the Ministerial text, it fixed the modalities of the execution of the project. Yaounde III Council took time to sensitise the population and in opening the tenders the Terms of Reference (ToR) defined the steps through which the project will be executed. These steps included:

- Feasibility studies which fixed the technical and financial conditions and the deadline of the project.

- Elaboration of the Urban Renovation Plan (URP) in conformity of the dispositions of Article 27 of urban laws [18].

In regards to the conditions of the contract, the land surface for the renovation project covers a surface area of $22,462.31 \mathrm{~m}^{2}$. In the process of sensitisation, 
the beneficiaries were called upon to contribute $20 \%$ of the total cost of each shop to be constructed according to the technical conditions of the project. From the estimation made, each beneficiary is to deposit the sum of 2,012,300 FCFA for a shop, 594,674 FCFA for a covered counter, 460,897 CFA for a counter in type 1 hangar and 1,620,675 FCFA for a counter in type 2 hangar. At the end of the project, these will all be handed over to the beneficiaries as they are programmed to pay the rest of the $80 \%$ of the total cost in monthly instalments for a period of five years. This money estimated includes all the taxes in accordance to the finance law inforce. From the analysis of the amount estimated to collect, the project is designed to be executed in six phases (Table 5 and Figure 10).

Table 5. Construction phases of the renovation project.

\begin{tabular}{|c|c|}
\hline Phases & Infrastructure programmed \\
\hline Phase 1 & Construction of 51 shops and 01 type 1 hangar \\
\hline Phase 2 & Construction of 37 shops and 01 type 2 hangar \\
\hline Phase 3 & $\begin{array}{l}\text { Construction of } 60 \text { shops } 15 \text { counters, } 01 \text { type } 2 \text { hangar, one bloc for toilettes and } 01 \\
\text { water point }\end{array}$ \\
\hline Phase 4 & $\begin{array}{l}\text { Construction of } 32 \text { shops, } 06 \text { counters } 02 \text { type } 1 \text { hangars, } 01 \text { bloc for toilettes and } 01 \\
\text { water point }\end{array}$ \\
\hline Phase 5 & $\begin{array}{l}\text { Construction of } 20 \text { shops and } 01 \text { type } 1 \text { hangar, Police post building, cold store, } \\
\text { warehouse and } 02 \text { showers }\end{array}$ \\
\hline Phase 6 & $\begin{array}{l}\text { Creation of parking spaces, extension area, circulation spaces, gutters, wiring, potable } \\
\text { water points and provision of garbage cans }\end{array}$ \\
\hline
\end{tabular}

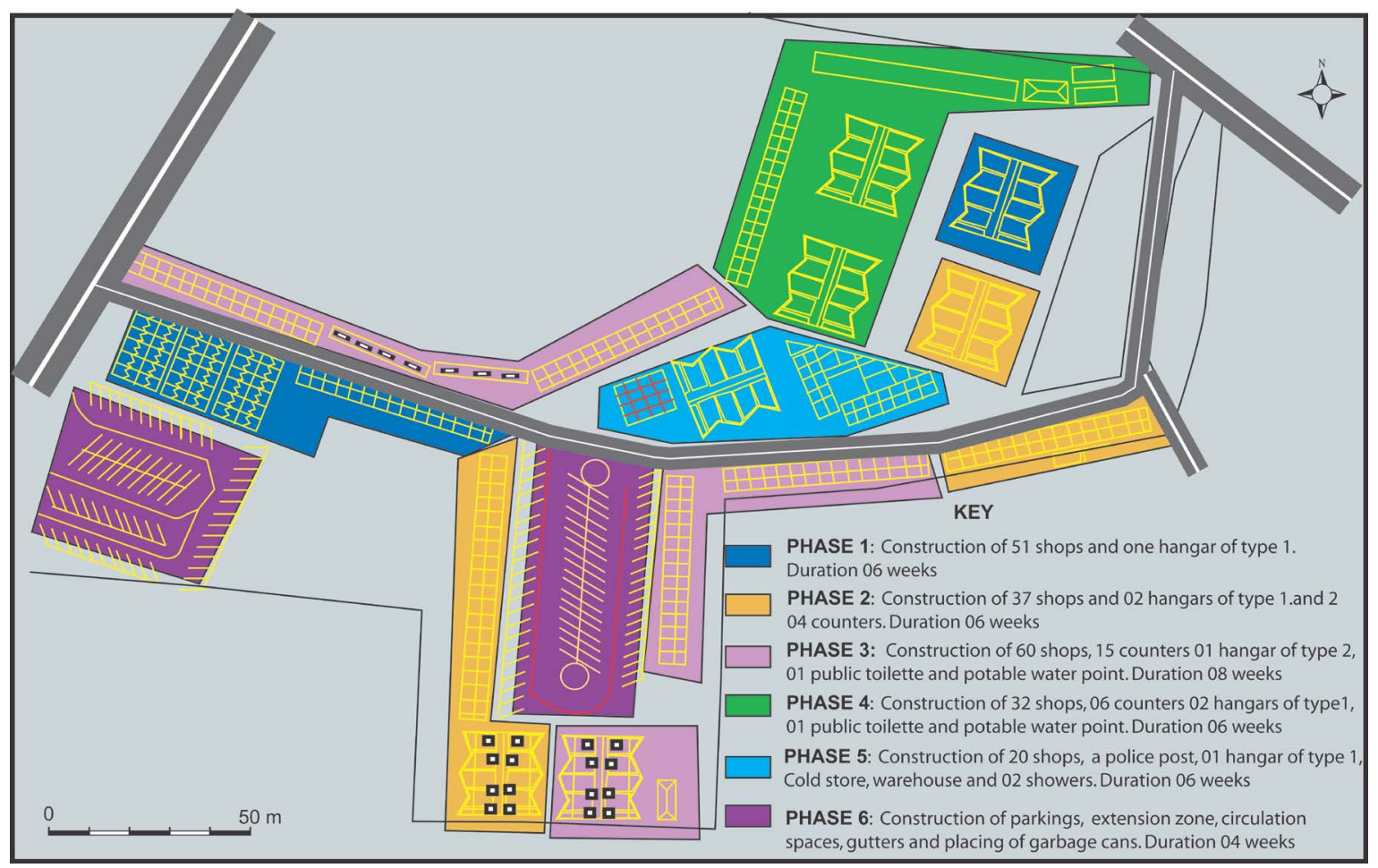

Figure 10. View of the different construction sections in 2D. 


\subsection{Programme of Executing the Project}

\subsubsection{Description of the Project}

The technical descriptive cost estimate aims at defining the consistence and the mode of executing the renovation project of the Nsam market. This is accompanied by graphic documents (plans) where one will be able to appreciate the facelift this market is to take. This project, if well executed according to the chronogram can last for 9 months. The steps to be followed include: setting up of the workplace, purchase and stocking of building materials, excavations (for the foundations and septic tanks), building the foundations, installation of underground pipes, raising the pillars, walls, pavements, roofing, flooring, wiring, canalisations, water installation and painting. Table 6 summarises the work to be done and the characteristics of each piece of work designed. Each of this piece of work has a period under which it has to be realised following the chronogram that was developed in the different phases.

\subsubsection{Technical Aspects of the Project}

This consists of the architectural design of the project, brief the state of the art through which one can appreciate the structure to be put in place. It constitutes an important aspect of the entire project because it is from it that one views the nature, the dimensions, the colour and the beauty of the infrastructure. Each

Table 6. Total work to be realised.

\begin{tabular}{|c|c|c|c|c|c|}
\hline Piece of work to do & Objective & Surface to cover & Number & $\begin{array}{l}\mathrm{N}^{\bullet} \text { of place per } \\
\text { work }\end{array}$ & Total capacity \\
\hline Shops & $\begin{array}{l}\text { For groceries, cosmetics, small hardware, } \\
\text { clothes etc }\end{array}$ & $16.22 \mathrm{~m}^{2}$ & 200 & 1 & 200 \\
\hline Grand hangars of type 1 & Sale of cereals, foodstuffs, meat, fish... & $393.24 \mathrm{~m}^{2}$ & 5 & 60 & 300 \\
\hline Grand hangars of type 2 & Restaurants and bouvets & $393.24 \mathrm{~m}^{2}$ & 2 & 16 & 32 \\
\hline Covered counters & Sale of essential goods and foodstuffs & $5.90 \mathrm{~m}^{2}$ & 21 & 1 & 21 \\
\hline Police post & Maintenance of law and order & $32.01 \mathrm{~m}^{2}$ & 1 & 6 & 6 \\
\hline Cold stores and warehouses & Conservation of goods & $152.34 \mathrm{~m}^{2}$ & 1 & 30 tons of goods & 30 tons of goods \\
\hline $\begin{array}{l}\text { Public toilettes and potable } \\
\text { water points }\end{array}$ & Hygiene and health & $36.60 \mathrm{~m}^{2}$ & 2 & 10 & 20 \\
\hline Parking & Security of vehicles & $1999.04 \mathrm{~m}^{2}$ & 1 & 68 vehicles & 68 vehicles \\
\hline Reorganising the motor park & $\begin{array}{l}\text { Render the park with optimal functioning. } \\
\text { Good management of vehicles }\end{array}$ & $2553.49 \mathrm{~m}^{2}$ & 1 & 82 vehicles & 82 vehicles \\
\hline Reconstruct infrastructure & $\begin{array}{l}\text { Improve on the passages and access to the } \\
\text { hangars }\end{array}$ & I & 1 & I & I \\
\hline Water adduction & Provide potable water in the market & / & 1 & 1 & I \\
\hline Electrical network & $\begin{array}{l}\text { Adequately supply electricity in all the } \\
\text { infrastructure }\end{array}$ & l & 1 & 1 & I \\
\hline Channelling & Good management of waste water and runoffs & I & 1 & 1 & I \\
\hline Garbage cans & Redefine waste collection and management & $7.5 \mathrm{~m}^{2}$ & 3 & - & $11.25 \mathrm{~m}^{3}$ \\
\hline
\end{tabular}


structure is accompanied by the view of ground plan, the perspective architectural plan in 3D and the estimated cost. Figure 11(a) and Figure 11(b) present the ground plans while Figures 12-17 are the architectural plans in 3D. Table 7 shows the estimated cost.

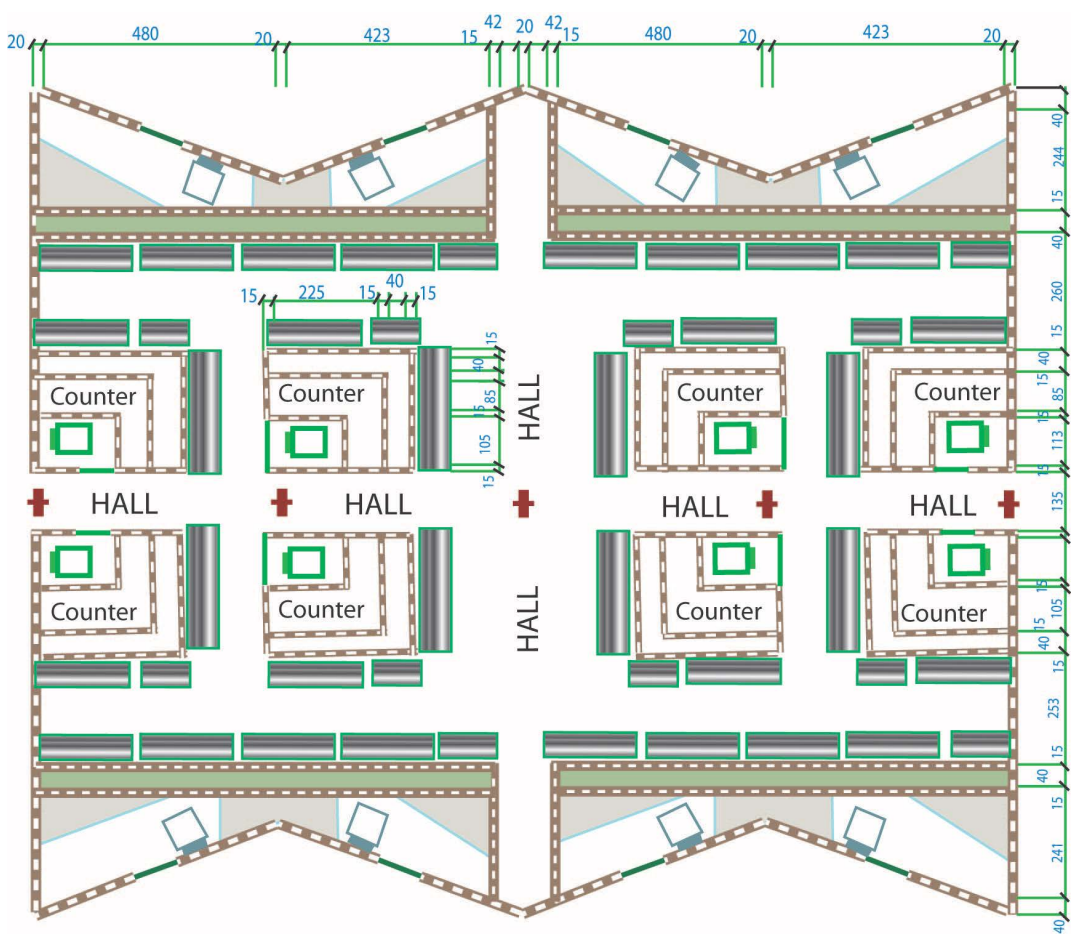

(a)

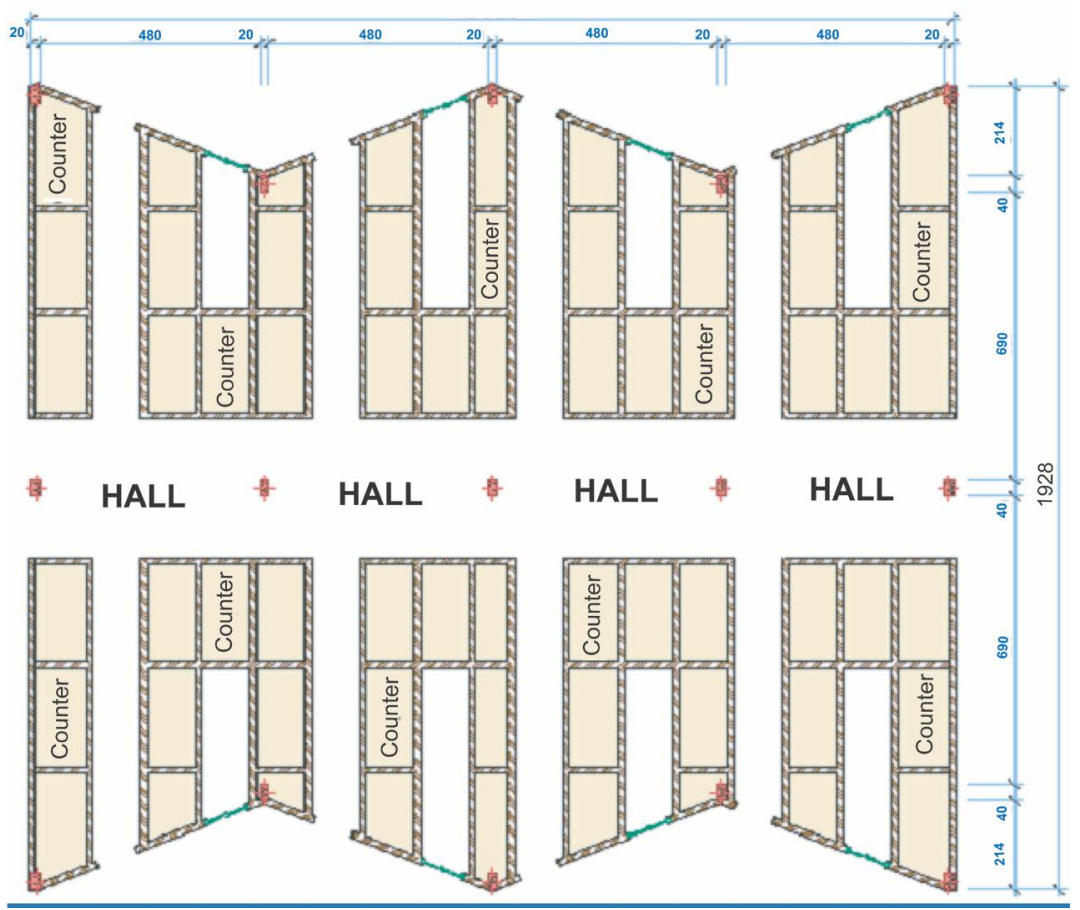

(b)

Figure 11. Ground plans of type 1 hangar. 


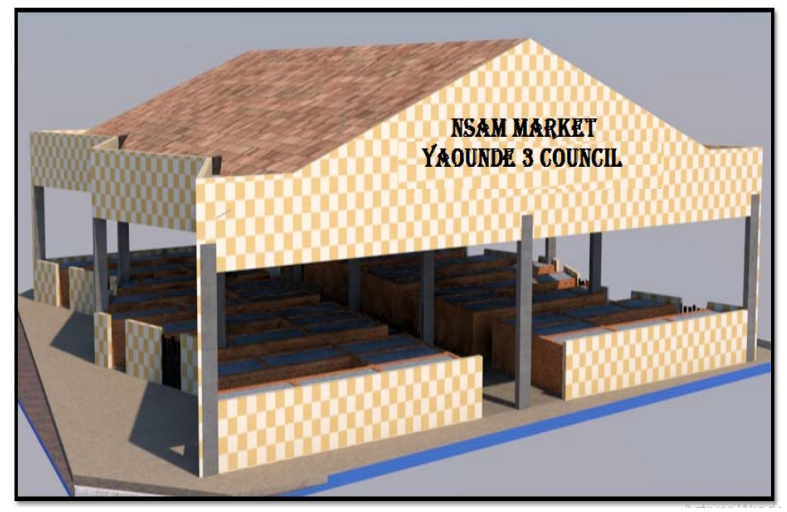

(a)

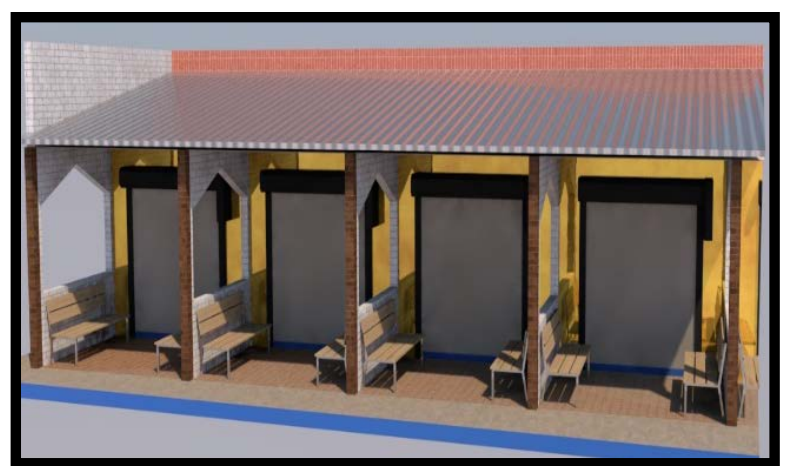

(b)

Figure 12. Architectural plans of type 1 hangar in 3D.

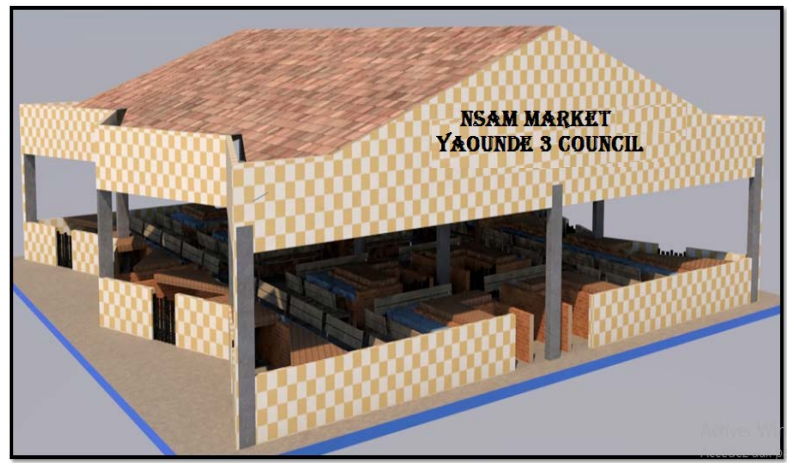

(a)

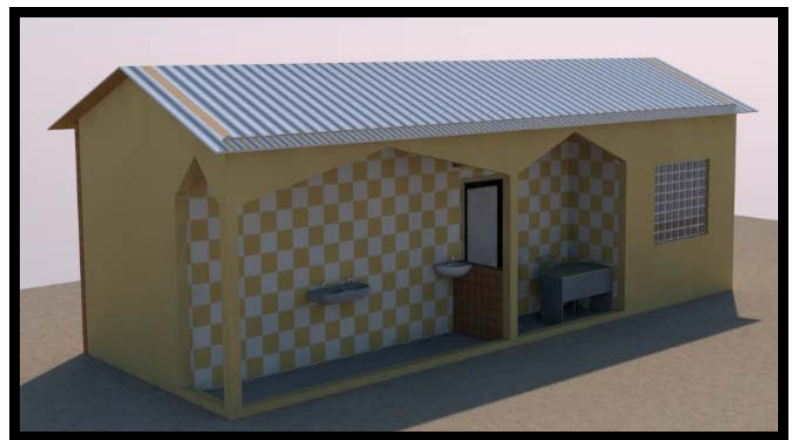

(b)

Figure 13. Model public toilette and type 2 grand hangar in 3D. 


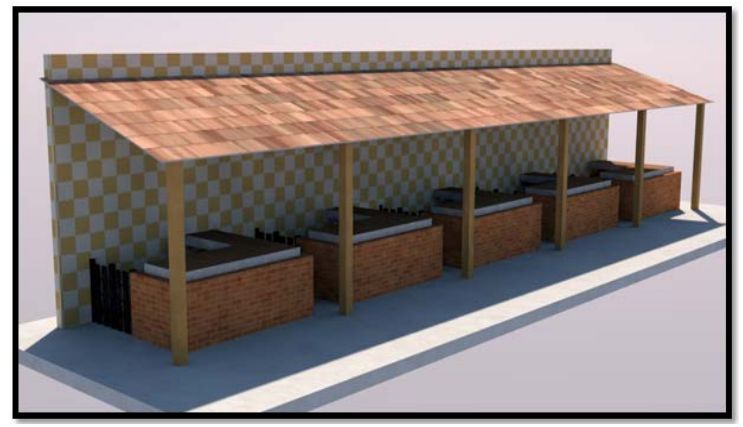

(a)

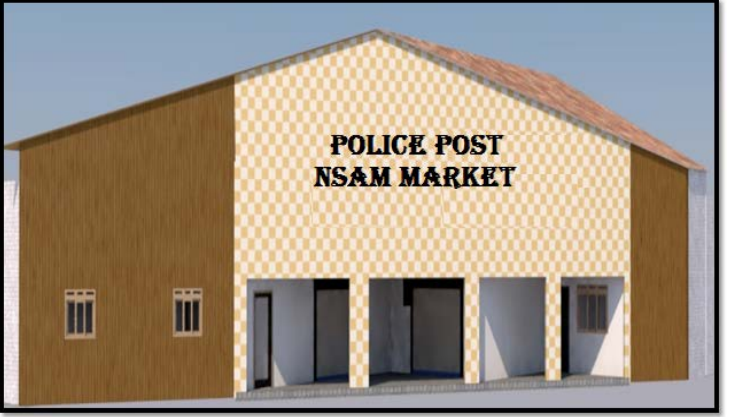

(b)

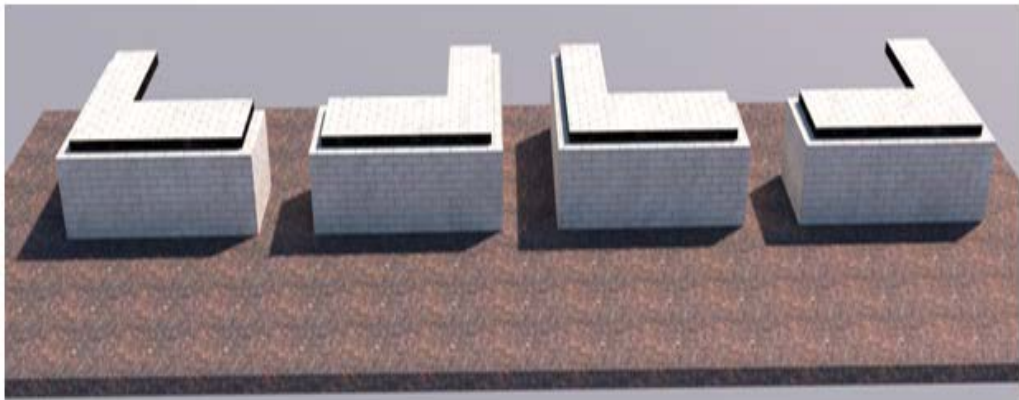

(c)

Figure 14. Police post in the market, covered counters and open counters.

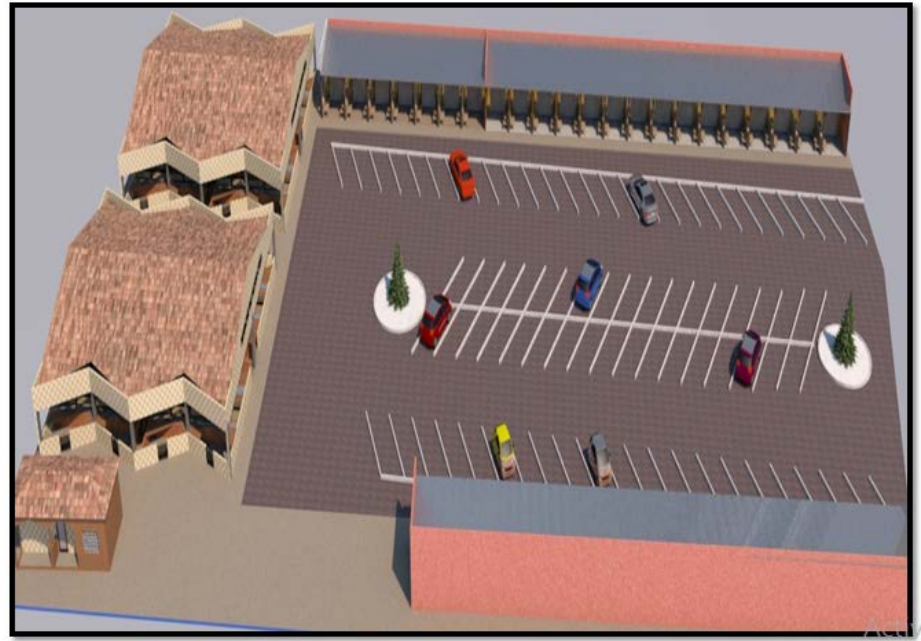

Figure 15. Motor park in the Nsam market. 


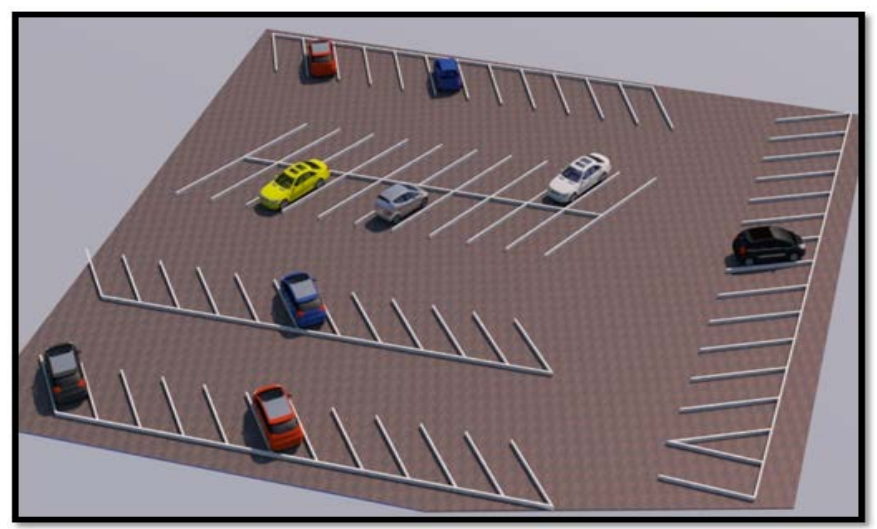

Figure 16. Parking lot in the Nsam market.

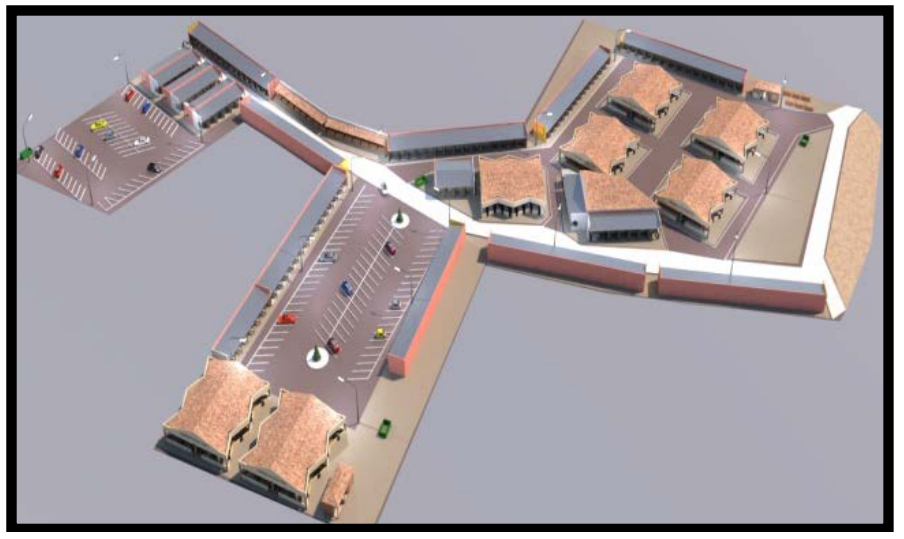

Figure 17. Aerial view of the proposed project in 3D.

Table 7. Global estimation of the cost of renovating Nsam market in Yaounde.

\begin{tabular}{|c|c|c|c|c|}
\hline Constructions to be realised & $\begin{array}{l}\text { Surface area } \\
\text { covered }\end{array}$ & $\begin{array}{c}\text { Number } \\
(\mathrm{N})\end{array}$ & $\begin{array}{l}\text { Unit cost } \\
\text { (in FCFA) }\end{array}$ & $\begin{array}{l}\text { Total cost } \\
\text { (in FCFA) }\end{array}$ \\
\hline Construction of shops & $16.22 \mathrm{~m}^{2}$ & 200 & $2,012,300$ & $402,460,000$ \\
\hline Construction of type 1 hangars & $393.24 \mathrm{~m}^{2}$ & 5 & $27,653,820$ & $138,269,100$ \\
\hline Construction of type 2 hangars & $393.24 \mathrm{~m}^{2}$ & 2 & $25,930,755$ & $51,861,510$ \\
\hline Construction of open air counters & $205.2 \mathrm{~m}^{2}$ & 15 & $594,673.3$ & $8,920,100$ \\
\hline Construction of ground counters & $136.6 \mathrm{~m}^{2}$ & 10 & 575,240 & $5,752,400$ \\
\hline Construction of the police post & $32.01 \mathrm{~m}^{2}$ & 1 & 1 & \multirow{2}{*}{$26,527,423$} \\
\hline Construction of cold store and warehouse & $152.34 \mathrm{~m}^{2}$ & 1 & I & \\
\hline Construction of public toilettes and water points & $36.60 \mathrm{~m}^{2}$ & 2 & $13,033,060$ & $26,066,120$ \\
\hline Construction of paid parking & $1999.04 \mathrm{~m}^{2}$ & 1 & $79,604.2$ & $159,132,140$ \\
\hline Construction of the motor park esplanade & $2553.49 \mathrm{~m}^{2}$ & 1 & $80,056.6$ & $204,423,965$ \\
\hline Building road pavements inside the market & $1925 \mathrm{~m}^{2}$ & & 25,000 & $48,125,000$ \\
\hline Reorganising the electrical network & I & 1 & $3,563,000$ & $3,563,000$ \\
\hline Building the general drainage system & $182.7 \mathrm{~m}^{2}$ & 1 & 15,000 & $2,740,500$ \\
\hline Purchase of garbage cans & $7.5 \mathrm{~m}^{2}$ & 3 & 250,000 & 750,000 \\
\hline Financing environmental impact assessment & I & 1 & $2,000,000$ & $2,000,000$ \\
\hline Financing the technical studies & I & 1 & $4,500,000$ & $4,500,000$ \\
\hline \multicolumn{4}{|c|}{ Total cost of the project } & $1,085,091,258$ \\
\hline
\end{tabular}




\section{Analysis}

In the year 2000, the international community defined what is commonly referred to as the Millennium Development Goals (MDGs) which were mostly destined for the developing countries. This initiative defined basic concepts for the wellbeing of human life that were earmarked to be attained the year 2015. Unfortunately most of the $3^{\text {rd }}$ world countries under this programme did not attain them. The international community again came up with Sustainable Development Goals (SDGs) which are in force today though with a high probability that the set objectives might still not be attained [19]. To develop an initiative is one thing, to implement it is another thing. What happens at the international level is also what happens in Cameroon. Year in year out, texts have been developed governing town planning but much leaves to be desired as far as their implementation is concerned. The project of renovating the Nsam market in Yaounde comes as another white elephant project which many wonder how far this will be implemented.

In conceiving this project, the aspect of how sure will it be implemented was seriously taken into consideration. In concretising that certainty, the first step was to explore the sources of finances for the project. Care was taken to ensure that each source identified must find its interest in this project. This interest fell within the contexts of the profit that could be generated, North-South Cooperation, humanitarian action or state agenda. It should be noted that financing a project heavily depends on the profitability that is expected and the possible writing off, if not limiting the risk that might crop up. In the first place, the owner of this project is the Yaounde III council. It has to make provision of a certain amount ( $46 \%$ to $60 \%$ ) of the total budget before other sources can be explored. These include:

State subventions; in this case, it can come through state organisations such as the Yaounde City Council, Special Fund for Intercommunal Intervention and Equipment (FEICOM), Ministry of Urban Development and Housing.

Public-Private partnership; here banks can independently carry out feasibility studies in order to determine the risks involved, the sustainability of the project and the profitability this might generate in the near future before getting into partnership with the Yaounde III council to realise this project. These banks include Afriland First Bank, Ecobank, BICEC, Societé Général etc. The actions of these banks are in conformity to the dispositions of Article 2 of Law N ${ }^{\circ} 2006 / 012$ of 29 December 2006 bearing on partnership contracts [20]. This law stipulates that the state or any of its organs can cede part or all of a contract to a third party ranging from conception, to construction, transformation and maintenance. But given the complexity of the project with its economic, financial, legal and administrative character, Yaounde III council alone cannot mount this project. Thus, the ideal decision is to open it up to tenders who will certainly give an expert view of the project.

Field investigation revealed that after the sensitisation campaign, $82.13 \%$ of 
the beneficiaries are ready to provide the $20 \%$ of the total cost expected from them before the beginning of the project. This means that before partners engage in the realisation of this project, Yaounde III council can single-handedly begin the project.

Lastly, international partnerships are also well placed to provide funding for such projects. This mostly falls within the framework of North-South Cooperation, South-South Cooperation and Development partners such as French Cooperation Agency (FCA), African Development Bank (ADB) and the World Bank [21].

In November 1993, various workshops and round table discussions were held in Cameroon in view of launching the activities of the National Environmental Management Plan (NEMP) following the recommendations of the Rio conference in 1992. This relates to environmental protection, thus, Environmental Impact Assessment (EIA) resulting from the realization of any giant project. This provision is inscribed in the Environmental Management Framework Act of 1996, which stipulates that changes in settlement conditions, employment and health of the local population are to be evaluated in the area where a giant project has been implemented. The cost of EIA must be included in the budget of that project which often swells the total cost of a project. This seems to be complex because the conditions of households are not often included in this assessment. But an acceptable method is when comparing the wellbeing of households before and after the project [22].

However, as regards positive impact, it is expected that many avenues of employment will be created in this part of Yaounde. This will mostly concern the youths as unemployment is one of the greatest cankerworm eating deep into the Cameroonian social fabric. The emergence of many and modern shops will accommodate many youths as sale-managers, transportation of goods and after sale services. Secondly, living conditions is expected to improve in this locality. These are in regard to security, environmental cleanliness and competition. Besides this, the market dwellers will have access to quality potable water, modern toilettes, secured electricity and drained paved surfaces. People will be able to circulate easily inside the market, goods better conserved and secured. The market authorities will develop easy accountability of the goods and number of sellers.

On the other hand, one should not ignore the fact that certain negative aspects can crop up which did not exist before. This mostly points to the period of the execution of the project. Certainly people will temporarily be displaced, atmospheric pollution will be generated, blockages and obstruction of traffic, accidents to the workers among others. Both the positive and the negative impacts will be categorized as being minor, moderate or major depending on the extent. Measures explored to attenuate the negative impacts of the project include; regulatory and technical measures as well as execution measures.

As for the former, there are a number of issues to be taken into consideration 
such as:

- An environmental and social impact studies must first be carried out in accordance with the provisions of the terms of reference of the project. While for the latter.

- Elaborate a technical study for the project first before the project is launched (as illustrated by the architectural plan).

- Designate a consultancy that will be charged with the follow up of the project during execution.

While on the latter, the execution measures before the launching of the project will ensure that:

- sensitization and communication is well echoed.

- a temporal displacement plan for the traders will be elaborated.

- hygiene and security measures respected.

- billboards and signboards put up during the execution of the project.

- buffer zone created.

- proper management of waste resulting from the execution of the project.

- and finally work hand in gloves with service suppliers such as ENEO (an electricity corporation) and $\mathrm{CDE}$ (potable water corporation).

\section{Discussion}

Before the initiation of this project, feasibility studies revealed that it was possible to realize the renovation of the Nsam market. First and foremost is the topography of the market. It is sloppy ranging between $2 \%$ to $3 \%$ of slope gradient which means possible to build. Secondly, when one takes a look at the functioning of the market, it shows that it functions below capacity. The congestion of buyers and sellers coming not only from the Nsam neighbourhood, but as far as satellite towns around Yaounde in spite of the poor structures, poor passage ways, etc is proof that it functions largely below capacity. Its location is a huge potential, that is, close to quarters that are dominantly residential such as $\mathrm{Da}$ mas, Olezoa, Barriere, Dakar etc which also favours exchanges with other markets such as Acacia, Mokolo, Mvog Mbi, Mfoundi.

From the diagnosis of the situation in Nsam market, it was discovered that since its creation need has always been for upgrading the standards. This is because the supply of goods largely satisfies demand though the functioning of the market is minimal. Secondly, the least activity carried out in the market can sustain a living. For example, a truck push raises about 45,000 to 50,000 frs CFA a month. More than $67 \%$ of the traders in the market buy the idea of renovating the market especially in aspects such as circulation, provision of potable water, construction of new toilettes and improved electricity supply to the hangars and the shops, while $33 \%$ proposed that the whole market be destroyed and rebuilt.

Furthermore, about $95 \%$ of the space occupied by the market do not face land conflicts. Thus, the traders are unanimous of the fact that the government through the council should take up its responsibility to renovate this market which will ease their working conditions. This responsibility can be in form of 
financial assistance to the traders as $32 \%$ of the respondents testified, physical assistance through the construction of infrastructure (58\%), morally through the satisfaction of the market dwellers in the management of waste and finally in a participative manner through good governance. It should be noted that about $78 \%$ of the traders in the Nsam market own the space on which they operate which can mortgage certain expenditures that could be incurred in compensating for land.

The physical outlook and the functioning of the Nsam market is an eyesore. These observations are classified and summarized on Table 8 that resulted from the diagnosis.

Table 8. Motivating factors to completely renovate the Nsam market.

\begin{tabular}{|c|c|c|}
\hline Problem & Causes & Consequences \\
\hline $\begin{array}{c}\text { Poor state of } \\
\text { basic infrastructure }\end{array}$ & $\begin{array}{l}\text { - Uncontrolled placing of goods in the market, some on the } \\
\text { bare ground while others are on passage ways } \\
\text { - counters blocking gutters } \\
\text { - no signboard along the main street indicating the presence } \\
\text { of a market } \\
\text { - commercial motorbikes blocking the main entrance to the } \\
\text { market }\end{array}$ & $\begin{array}{l}\text { - Poor circulation in the market, congestion of } \\
\text { people, thus theft } \\
\text { - narrow passage ways } \\
\text { - accelerated degradation of the passage ways } \\
\text { - exposure to pick pockets especially on Saturdays } \\
\text { - difficult to identify the entrance to the market }\end{array}$ \\
\hline Hygiene and insalubrity & $\begin{array}{l}\text { - Poor management of waste } \\
\text { - no plan for the construction of warehouses and hangars } \\
\text { - dilapidated toilettes } \\
\text { - degraded counters for the sale of meat } \\
\text { - stagnated waste water coming from the cleaning of fowls } \\
\text { - use of plastic materials to burn cow skin } \\
\text { - absence of pre-collecting garbage cans } \\
\text { - sale of goods at the proximity of garbage heaps } \\
\text { - exposure of some goods to the sun }\end{array}$ & $\begin{array}{l}\text { - a lot of flies } \\
\text { - risk of intoxication around the burning of cow } \\
\text { skin } \\
\text { - risk of disease infection around the cleaning of } \\
\text { fowls } \\
\text { - pollution with the production of toxic smoke } \\
\text { - bad odours in some parts of the market }\end{array}$ \\
\hline $\begin{array}{l}\text { Insecurity of } \\
\text { people and goods }\end{array}$ & $\begin{array}{l}\text { - poor quality of building materials } \\
\text { - dilapidating roads } \\
\text { - Guard of warehouses entrusted in the hands of untrained } \\
\text { night vigils } \\
\text { - consumption of drugs to boost work at job sides } \\
\text { - } \text { insufficient police personnel } \\
\text { - no fence around the market } \\
\text { - no identification of truck pushers } \\
\text { - } \text { sale of uncontrolled alcohol (odontol, bilibili) }\end{array}$ & $\begin{array}{l}\text { - risk of theft in the warehouses } \\
\text { - muddy passage ways during the rainy season } \\
\text { - the extension side already occupying the newly } \\
\text { tarred road } \\
\text { - various risks (fighting among the traders, theft of } \\
\text { goods) }\end{array}$ \\
\hline $\begin{array}{l}\text { Difficult access } \\
\text { to potable water }\end{array}$ & $\begin{array}{l}\text { - Frequent cutting of water } \\
\text { - rusting of water supply pipes } \\
\text { - contamination }\end{array}$ & $\begin{array}{l}\text { - poor quality of potable water } \\
\text { - exposure to water related diseases } \\
\text { - drinking untreated rain water }\end{array}$ \\
\hline $\begin{array}{l}\text { Poor management } \\
\text { of electricity network }\end{array}$ & $\begin{array}{l}\text { - complicated subscription process } \\
\text { - poorly connected light in warehouses and in shops } \\
\text { - no crosschecking of the existing network } \\
\text { - corruption and ignorance of the traders }\end{array}$ & $\begin{array}{l}\text { - proliferation of wrong connections } \\
\text { - risk of fire outbreaks } \\
\text { - low voltage } \\
\text { - frequent electricity cuts due to short circuits }\end{array}$ \\
\hline $\begin{array}{l}\text { Unorganized functioning } \\
\text { of the motor park }\end{array}$ & $\begin{array}{l}\text { - presence of abandoned vehicles inside the park } \\
\text { - overloading of vehicles } \\
\text { - poorly organized space }\end{array}$ & $\begin{array}{l}\text { - saturated space } \\
\text { - presence of open garbage heaps }\end{array}$ \\
\hline $\begin{array}{l}\text { Difficult access to the } \\
\text { market }\end{array}$ & $\begin{array}{l}\text { - blockage by commercial motorbike riders } \\
\text { - many ambulant traders }\end{array}$ & $\begin{array}{l}\text { - no signboard indicating access to the market } \\
\text { - traffic and peoples' congestion }\end{array}$ \\
\hline
\end{tabular}




\section{Conclusions}

Decree No 2008/0738 of $23^{\text {rd }}$ April 2008 defines many terms which sometimes orchestrate confusion among town planners in Cameroon. These terms among others include renovation, rehabilitation, restructuring and restoration. This study focused on renovation which is defined by the town planning governing text as a set of measures and planning operations that consist of total or partial demolition of dilapidated or in-adapted urban sector in order to raise new structures. No matter who take the decisions for renovation, as the text defines many stakeholders, the present study identified the Yaounde 3 Council as the owner of this project. This corporate body defined the terms of reference and opened it up to tenders. It is within this context that the renovation project for the Nsam market in Yaounde is proposed with a global envelope of 1,085,091,258 FCFA.

The study heavily relied on feasibility studies, evaluating the construction site, assessing the cost and estimating the number of direct beneficiary people. Going from an image of the aerial view of the site, screen capture was made from Google Earth image, geo-referenced with ArcGIS software and later integrated into Archicad where the architectural design was made.

From field observations coupled with computer operations, the diagnosis proved that a complete renovated Nsam market is necessary. With about $67 \%$ of the traders ready to contribute the expected $20 \%$ demanded before the commencement of the project is proof of this necessity. Financial bodies such as local banks, government agencies as well as Cameroon's development partners identified can engage in this project which will not only better the working conditions of the traders in this market but will also create jobs and embellish Yaounde city.

\section{Acknowledgements}

We wish to express gratitude to the authorities of the University of Yaounde I for creating a professional master in Town Planner and Urban Development which went operational in the Department of Geography since 2010-2011 academic year. It is through the context of this programme that this study was carried out.

\section{Conflicts of Interest}

The authors declare no conflicts of interest regarding the publication of this paper.

\section{References}

[1] Law 2004/003 of 21 April 2004 Governing Town Planning in Cameroon and Its Application Texts.

[2] World Bank (1994) Cameroon; Diversity, Growth and Poverty Reduction. Working Draft, Human Resource and Poverty Division, Technical Development. 
[3] Benoît, M. (2003) Urbanisme participatif: Utopies ou réalités. Cas du quartier Nkolmesseng à Yaoundé. Cameroon Geographical Review, 15, 16-29.

[4] Michele M'Packo (Cameroun) (2000) Violence, Délinquence and Insecurity in Douala-Cameroon. $18 \mathrm{p}$.

[5] Leu, P. (2008) Le marché urbain: Intervention de developpement et mode d'appropriation par les acteurs locaux. Le cas of Grand Marché aux légumes à Ouahigouya (Burkina Faso). Masters Dissertation in Geography, 95 p.

[6] Nyambod, E.M. (2010) Geographic Information Systems as a Tool for Participatory Land Administration. North West Region of Cameroon, Bamenda.

[7] Mabou, P.B. (2000) Dégradation of cadre de vie et réactions des associations volontaires et civiles dans la zone péricentrale de la ville de Yaoundé: Cas of quartier Nkoldongo. Masters Dissertation in Geography, University of Yaoundé I, Yaoundé, $186 \mathrm{p}$.

[8] Williamson, I., Wallace, J. and Rajabifard, A. (2006) Spatially Enabling Governments: A New Vision for Spatial Information. Centre for SDIs and Land Administration, Department of Geomatics, the University of Melbourne, Victoria, 13 p.

[9] Elong Ngando Epossy Marthe (2013) Réamenagement des quartiers péricentraux anciens de la ville de Yaoundé: Le cas du quartier Mvog-Mbi. Masters Dissertation in Geography, $160 \mathrm{p}$.

[10] Alan, G. and Josef, C.O. (1992) Cities, Poverty and Development. Urbanization in Third World. 2nd Edition, Oxford University Press, Oxford, $331 \mathrm{p}$.

[11] Kengne Fodouop, F. (1991) Les problèmes environnementaux dans les grandes villes Camerounaises. In: La situation de Penvironnement au Cameroun, Fondation Friedrich-Erbert, Yaounde, 5-25.

[12] Abah, O.L. (1990) Etude de l'aménagement des quartiers péricentraux de Yaoundé. Masters Dissertation in Geography, Université de Yaoundé I, Yaoundé, 103 p.

[13] Fadimatou Zina Njoya (2016) Réamenagement of quartier Akok Ndoe I dans la commune d'arrondissement de Yaoundé VI. Masters Dissertation in Geography, $170 \mathrm{p}$.

[14] Ministry of Urban Development and Housing (1989) SDAU, PDL, PUS Town Planning Guides for the Republic of Cameroon. $173 \mathrm{p}$.

[15] Decree $n^{\circ} 2008 / 0739 / \mathrm{PM}$ of 23 April 2008 Fixing the Rules of Land-Use and Various Constructions.

[16] Decree $n^{\circ} 2008 / 074 / P M$ of 23 April 2008 Fixing the Sanctions That Are Applicable to Defaulters in Applying the Norms of Town Planning in Cameroon.

[17] Decree $n^{\circ} 2008 / 0738 / \mathrm{PM}$ of 23 April 2008 Bearing on the Organisation of the Procedures and Modalities for Land Management.

[18] Local Economic Development Plan, February (2009) Destined to the Yaounde 3 Council Area.

[19] Ansu, Y., McMillan, M., Page, P. and Willem Te Velde, D. (2016) Promoting Manufacturing in Africa. African Transformation Forum, Kigali, 14-15 March 2016, 17 p.

[20] Law N ${ }^{\circ} 2006 / 012$ of 29 December 2006 Bearing on the General Regime of Partnership Contracts.

[21] Poyau, A. (2005) Les récentes mutations des marchés urbains dans la capitale économique ivoirienne. Université de Provence UFR des Sciences géographiques et de l'aménagement of territoire Laboratoire Telemme. 126 p. 
[22] Foret, C. and Françoise Porchet, C.O.F. (2000) Urban Rehabilitation, Department of Town Planning, Housing and Construction. Documentation Centre for Town Planning, Manit, $380 \mathrm{p}$. 